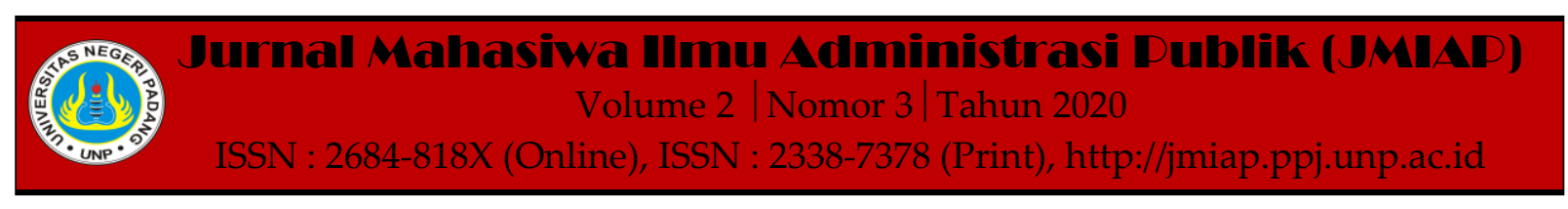

\title{
KENDALA PERAN PEREMPUAN DALAM PENGURANGAN RESIKO BENCANA GEMPA BUMI DAN TSUNAMI DI KELURAHAN AIR TAWAR BARAT
}

\author{
Khairunnisa $^{1(a)}$, Zikri Alhadi ${ }^{2(b)}$ \\ ${ }^{1}$ Jurusan Ilmu Administrasi Negara, Universitas Negeri Padang \\ ${ }^{2}$ Jurusan Ilmu Administrasi Negara, Universitas Negeri Padang \\ a)khairunnisaaa0704@gmail.com, ${ }^{b}$ zikrialhadi@fis.unp.co.id
}

\begin{abstract}
This study aims to find out what are the constraints on the role of women in reducing the risk of the earthquake and tsunami disaster in Air Tawar Barat Village. women were the most vulnerable group when the earthquake and tsunami occurred. In the research conducted using a qualitative descriptive method. The technique of determining research informants by means of purposive sampling. Data collection techniques by means of observation, interviews, and documentation. Data analysis techniques are reduction, data presentation and conclusion. Technique of validity of research data is source triangulation. There are 2 obstacles faced by the role of women in reducing the risk of the earthquake and tsunami disaster in Air Tawar Barat Village, namely internal and external constraints. The results show that the internal constraints are that BPBD has not integrated gender issues into disaster risk reduction activities, while the external obstacle is the lack of understanding, awareness, vigilance and concern for the women community.
\end{abstract}

Keywords : Constraints on the Role of Women, Disaster Risk Reduction

Corresponding author. Email.khairunnisaaa0704@gmail.com,zikrialhadi@fis.unp.co.id

How to cite this article. Khairunnisa \& Alhadi, Zikri. (2020). Kendala Peran Perempuan dalam Pengurangan Resiko Bencana Gempa Bumi dan Tsunami di Kelurahan Air Tawar Barat. Jurnal Mahasiwa Ilmu Administrasi Publik (JMIAP) Jurusan Ilmu Administrasi Negara Fakultas Ilmu Sosial Universitas Negeri Padang, Volume 2 (3), Hal. 26-33.

http://jmiap.ppj.unp.ac.id

ISSN : 2684-818X (Online), ISSN : 2338-7378 (Print)

Copyright $\odot 2020$. Published by Labor Jurusan Ilmu Administrasi Negara FIS UNP, Padang 


\section{PENDAHULUAN}

Banyaknya bencana yang terjadi di Indonesia menciptakan dampak dan beban yang besar yang dirasakan antara kelompok laki-laki dan perempuan, yang mana dampak dan beban yang dirasakan juga dirasalkan berbeda oleh beberapa lansia dan juga kalangan difabel. Antara laki-laki dan perempuan memiliki perbedaan pengaruh yang bisa di deksripsikan dengan aspek kerentanan, kapasitas, hambatan dan juga peluang. Pada saat bencana, antara laki-laki dan perempuan sering sekali terjadi kehilangan kapasitas untuk bisa mempertahankan kehidupan keluarganya yang mana saat setelah terjadi bencana mereka dapat kehilangan sumber penghasilan yang sudah dimiliki. Perubahan peran gender akan terjadi setelah bencana, mislanya laki-laki yang istrinya meninggal akibat bencana gempa bumi atau tsunami dan harus mengambil peran gender, dan sebaliknya. Walaupun laki-laki dan perempuan memiliki kerentanan yang tidak sama akan tetapi pada umumnya perempuan, anak-anak,dan lansia yang lebih berisko terkena dampak bencana gempa bumi dan tsunami.

Kota Padang, tepatnya di Kecamatan Padang Utara, Kelurahan Air Tawar Barat terletak di sepanjang pesisir pantai dan umunya rumah penduduk di bibir pantai. Luas Kelurahan Air Tawar Barat kecamatan Padang Utara yaitu 133.68 ha. Dengan batas wilayah Kelurahan Air Tawar Barat, yakni:

a. Utara : Kelurahan Parupuak Tabing.

b. Timur :Kelurahan Air Tawar Timur.

c. Selatan : Kelurahan Ulak Karang.

d. Barat : Samudera Indonesia.

Wilayah Kota Padang memiliki luas $1.414,96 \mathrm{Km} 2$ yang terdiri dari 11 Kecamatan dan 104 Kelurahan. Kota Padang merupakan daerah yang rawan bencana gempa bumi dan guncangan dengan berskala kecil akan tetapi lebih sering terjadi dan tidak berpotensi tsunami, akan tetapi jika gempa bumi yang terjadi di Kota Padang dengan guncangan bersakala besar maka akan berpotensi tsunami yang biasa mengancam wilayah Kota Padang dan sekitarnya. Penduduk Kota Padang pada umunya bertempat tinggal di tepi pantai tepat bibir pantai untuk dapat mempertahankan bahkan meningkatkan inflasi perekonomian penduduk pesisir pantai tersebut, dan bahwasannya para wisatawan datang berkunjungi untuk melihat keindahan pantai di Kota Padang hal ini yang meningkatkan pertumbuhan perekonomian masyarakat pesisi untuk bisa bertahan hidup.

Kota Padang merupakan daerah yang rawan gempa bumi walaupun tidak berpotensi tsunami akan tetapi lebih sering terjadi guncangan gempa bumi berskala kecil bahkan menengah yang bisa mengancam bangunan yang rentan roboh. Pada tanggal 30 september tahun 2009 Gempa bumi yang terjadi begitu dahsyat di Kota Padang yang mengakibatkan kerugian meteril bahkan korban jiwa yang di timbun oleh reruntuhan bangunan jumlah korban yang separuh dari jumlah penduduk yang ada di Kota Padang. Perempuan merupakan salah satu korban gempa bumi terbanyak dari pada laki-laki yakni 126 korban lakilaki dan 204 korban perempuan (BPBD Kota Padang 2010).

\section{Tabel 1. Rekaptulasi Korban Meninggal Berdasarkan Jenis Kelamin Karena Gempa Bumi 30 September 2009 Kota}

\begin{tabular}{|c|c|c|c|}
\hline \multicolumn{4}{|c|}{ Padang } \\
\hline \multirow{2}{*}{ NO } & \multirow{2}{*}{ KECAMATAN } & \multicolumn{2}{|c|}{ JENIS KELAMIN } \\
\hline & & LAKI-LAKI & PEREMPUAN \\
\hline 1 & PAUH & 4 & 9 \\
\hline 2 & KOTO TANGAH & 9 & 10 \\
\hline 3 & PADANG SELATAN & 15 & 20 \\
\hline 4 & PADANG UTARA & 9 & 17 \\
\hline 5 & PADANG TIMUR & 16 & 22 \\
\hline 6 & PADANG BARAT & 34 & 47 \\
\hline 7 & NANGGALO & 9 & 18 \\
\hline 8 & KURANJI & 14 & 24 \\
\hline 9 & LUBUK BEGALUNG & 12 & 28 \\
\hline 10 & LUBUK KILANGAN & 2 & 3 \\
\hline 11 & BUNGUS & 2 & 6 \\
\hline & TOTAL & 126 & 204 \\
\hline
\end{tabular}

Sumber : BPBD Kota Padang

Perempuan merupakan korban meninggal paling banyak sekitar $60 \%$ pada peristiwa gempa bumi di Kota Padang pada tahun 2009. Anak-anak, lansia dan orang yang berkebutuhan khusus juga merupakan 
korban meninggal paling banyak pada gempa bumi 30 September 2009 di Kota Padang. (BPBD Kota Padang,2011). Pada kenyataanya kelompok perempuan dan anak-anak memiliki resiko meninggal lebih besar dibanding laki-laki dewasa 14 kali lebih besar (Peterson K, 2007).

Jumlah penduduk di Kelurahan Air Tawar yaitu 15.770 jiwa, yang terdiri dari penduduk laki-laki yaitu 7.036 dan penduduk perempuan 8.734 (BPS, 2017). Jumlah penduduk perempuan lebih banyak dari pada laki-laki di Kelurahan air Tawar Barat dan upaya untuk meminimalisir korban jiwa terutama pada kelompok perempuan yaitu dengan mengadakan kegiatan kebencanaan seperti sosialisasi, edukasi dan simulasi untuk masyarakat perempuan, pada umumnya kelompok perempuan yang paling rentan jika terjadi bencana dan dan memiliki peran sebagai kebutuhan domestic bagi keluarga dan penenang bagi keluarga terutama trauma pada anak setelah terjadinya bencana.

BPBD Kota Padang sudah membentuk Kelompok Siaga Bencana (KSB) yang dibentuk secara sukarela di 104 Kelurahan di Kota Padang. Pemahaman, edukasi dan sosialisasi dan sebagainya yang dilakukan KSB Kelurahan bersumber dari BPBD Kota Padang dan KSB lah yang melaksanakan kegiatan sosialisasi ke lapangan untuk pengurangan resiko bencana gempa bumi dan tsunami. Kelompok Siaga Bencana tidak semuanya aktif di 104 Kelurahan di Kota Padang, hanya 20\% yang aktif karena sulit untuk bisa melakukan sosialisasi ke rumah-rumah masyarakat sangat tidak efektif, dan minimnya sarana dan prasarana yang di dapat untuk melaksanakan kegiatan yang ada di KSB Kelurahan. Kesenjangan gender juga sering terjadi pada saat kegiatan dilaksanakan. KSB Kelurahan Air Tawar Barat termasuk salah satu yang aktif dalam kegiatan KSB. Edukasi, sosialisasi, mitigasi bencana dan simulasi diadakan dan dilatih kepada masyarakat perempuan untuk dapat mempersiapkan kondisi masyarakat dalam menghadapi bencana gempa bumi dan tsunami dan dapat meminimalisir tingkat kepanikan sebagai dampak terjadinya bencana yang dapat menambah jatuhnnya korban jiwa. Dalam kegiatan yang dilaksanakan oleh BPBD Kota Padang melalui KSB kelurahan tidak terlepas dari partisipasi dan dukungan dari masyarakat. Untuk dapat meningkatkan peran, pemahaman dan kepedulian masyarakat terhadap pengurang resko bencana gempa bumi dan tsunami yang tercantum di dalam Undang-undang Nomor 24 tahun 2007 tentang Penanggulangan Bencana. Partisipasi dari masyarakat yang menunjukan upaya pengurangan resiko bencana yang berada di daerah yang rawan bencana seperti di bibir pantai secara mendiri untuk dapat meminimalisir kan kerentanan baru.

Dari latar belakang yang telah dijelaskan diatas, tujuan yang hendak dicapai dari penelitian ini adalah untuk mengetahui kendala peran peremuan dalam pengurangan resiko becana gempa bumi dan tsunami di Kelurahan Air Tawar Barat.

\section{TINJAUAN PUSTAKA}

Kendala merupakan suatu faktor yang dapat menghambat suatu proses program yang dilaksanakan secara internal maupun eksternal dari organisasi. Berdasarkan hasil penelitian, peneliti menemukan adanya kendala peran perempuan dalam pengurangan resiko bencana gempa bumi dan tsunami di Kelurahan Air Tawar Barat pada pelaksanaanya. Sesuai dengan teori Hansen dan Mowen yakni adanya hambatan yang terjadi berasal dari dalam/ luar organisasi atau perusahaan tersebut (Hansen 2007). Hastuti (2016) menjelaskan bahwasannya perempuan mempunyai peran 
yang strategis dalam pengurangan resiko bencana dan untuk meningkatkan kemampuannya dan dapat mengurangangi resiko bencana yakni dengan meningkatkan kesadaran, pemahaman, kewasapadaan, kepedulian dan kemampuan perempuan untuk menilai resiko, merencanakan dan melakukan sebuah tindakan, memantau dan juga mengevaluasi. Kerentanan dan pengukuran kapasitas dikemukakan oleh Wignayosukarto, (2007) yaitu suatu kondisi dimana penurunan ketahanan yang dapat mempengaruhi ancaman dari luar yang dapat mengancam kehidupan, sumberdaya alam, produktivitas ekonomi, pembangunan dan kesejahteraan. Keterkaitan antara kerentanan dan bencana dapat menciptakan keadaan yang berisiko, jika keadaan tersebut di laksanakan dengan efektif. Menurut Hastuti (2016:18) kemamapuan yang dimiliki oleh perempuan untuk bisa memantau, mengevaluasi dan memastikan kelangsungan pengurangan resiko bencana agar dapat meminimalisir dan mencegah resiko bencana. pemantauan dan pengevaluasian dilaksanakan oleh BPBD Kota Padang dan penetu dari keberhasilan perencanaan dan tindakan bahkan sudah sejauh mana respon dan tindakan dari masyarakat. Berdasarkan pemahaman diatas, peneliti dapat menyimpulkan bahwasannya peran perempuan dalam pengurangan resiko bencana sangatlah penting mengingat perempuan merupakan kelompok yang lebih rentan dan meningkatnya korban jiwa jika terjadi bencana, peran perempuan dalam kegiatan bencana sangat diharuskan seperti, mencari makanan dan minuman, penenang bagi anak trauma, menyiapkan air bersih, memasak dll, akan tetapi masyarakat perempuan masih belum memahami arti penting peran nya dalam pengurangan resiko bencana gempa bumi dan tsunami, maka dari itu peneliti menuliskan kendala peran perempuan dalam pengurangan resiko bencana gempa bumi dan tsunami di kelurahan Air Tawar Barat.

Menurut Denny Hidayati dkk, (2006:14) menjelaskan bahwasannya pengetahuan tentang bencana yang dimiliki oleh masyarakat perempuan dapat mempengaruhi pemahaman, sikap, kesadaran, kepedulian, kewaspadaan, masyarakat perempuan tentang resiko dan bencana yang dapat mengurangi resiko bencana. pada umumnya masyarakat tidak memahami akan resiko yang akan didapat. Kemampuan dan pemahaman yang dimiliki dapat menilai resiko perempuan sebagai indiviu, keluarga bahkan masyarakat. Peran perempuan sangat penting dalam kegiatan kebencanaan gempa bumi dan tsunami, perempuan sangat dilibatkan dalam kebutuhan domestic dan penenang keluarga terutama bagi anak yang trauma. Pemahaman resiko dari masyarakat sangat minim, masyarakat perempuan di Kelurahan Air Tawar Barat masih menolak jika diadakan sosialisasi, edukasi dan simulasi dari Kelompok Siaga Bencana Kelurahan Air Tawar Barat tanpa memikirkan resiko yang akan terjadi pada diri sendiri, keluarga bahkan masyarakat sehingga pelaksanaan kegiatan yang di laksanakan oleh KSB tidak berjalan dengan efektif.

Pada pra, saat, pasca bencana gempa bumi dan tsunami perempuan lah yang mengalami penderitaan lebih berat dan mudah panik jika terjadi bencana dan dalam penanganan bencana. bahkan sering terjadi kesenjangan gender yang dapat mengalihkan posisi perempuan sehingga mempunyai posisi tawar yang sangat rendah. Pada kodratnya perempuan dianggap sebagai kelompok yang sangat lemah, dan mengakibatkan peran perempuan pada pra, saat dan pasca bencana sangatlah rendah. Dan pada umumnya kelompok perempuan yang mempunyai tugas domestik, seperti kebutuhan, didapur dan masak memasak dan lain sebagainya, padahal seharusnya kelompok perempuan juga mempunyai hak dan kewajiban yang setara dengan kelompok laki-laki pada saat bencana. adanya kesenjangan sosial ini mengakibatkan peran perempuan dan lakilaki memiliki posisi yang berbeda dalam 
manajemen bencana (Siti Hidayati, 2019). Membentuk program dalam Pengurangan resiko bencana dapat meminimalisir korban jiwa pada bencana. Nurjanah dkk, (2013) mengutarakan bahwa pengurangan resiko bencana yakni suatu paradigma yang fokus pada, analis resiko bencana, ancaman, kerentanan dan kemampuan masyarakat tersebut. Pramana (2008) mengemukakan paradigma pengurangan resiko bencana yakni kombinasi dari perspektif teknis dan juga ilmiah terhadap keadaan dari kondisi ekonomi, sosial, lingkungan, dan politik.

Awatona dalam Permana (2010) mengemukakan bahwa di tentukan dari besarnya potensi resiko yang di ciptakan, bahaya adalah sebuah fenomena alam maupun buatan yang mempunyai kemampuan yang dapat mengakibatkan resiko kehidupan sosial, kerugian meteril, dan lingkungan yang rusak. Pada umunya masyarakat tinggal di bibir pantai agar dapat meningkatkan potensi perekonomian yang semakin meningkat, karena seperti yang diketahui bahwa pesisir pantai merupakan tempat pariwisata yang mana wisatawan akan datang berlibur. Pemahaman masyarakat pada situasi lingkungan dan ancaman bahaya di kelurahan Air Tawar Barat masih sangat minim, beberapa sebagian masyarakat bertahan dan memilih untuk tetap tinggal di bibir pantai untuk menunjang perekonomian mereka dan sebagian dari mereka berprofesi sebagai nelayan dan walaupun pada umunya masyarakat tahu akan ancaman bahaya dan resiko tinggal di bibir pantai akan tetapi tetap meningkat perekonomian dan memiliki hidup yang lebih layak.

Gender merupakan sebuah bentukan manusia, yang maksudanya bukan kodrat yang dapat berubah pada waktu tertentu. Jenis kelamin pada laki-laki dan perempuan merupakan kodrat, sementara gender bisa berpindah peran, seperti laki-laki bisa memasak, mencuci piring, mengurus anak, menyapu dan semua pekerjaan perempuan pada umumnya sebagai ibu rumah tangga, dan sebaliknya perempuan bekerja diluar rumah, sebagai penjabat ikut serta dalam pertemuan-pertemuan, berburu, bertukang, mengojek dan pekerjaan laki-laki pada umumnya dan tidak ada batasan kodrat. Menurut Smith dalam Puspitawati (2012) gender yaitu sebuah pandangan konstruksi yang juga pengetahuan dan inflasi analisis material. Dan melewati analisis gender peneliti dapat menelaah ketidakadilan dan ketidaksetaraan gender antara laki-laki dan perempuan yang disebakan oleh kebudayaan manusia dan bangunan peradaban. Untuk berpartisipasi dalam pengarustamaan gender pada bidang penanggulangan bencana, Badan Nasional Penanggulangan Bencana (BNPB) telah menetapkan sebuah peraturan Kepala BNPB Nomor 13 Tahun 2014 yakni tentang Pengarustamaan Gender pada bidang Penanggulangan Bencana. pada pasal 5 perka ini menjelaskan dalam penyusunan kebijakan, kegiatan dan program dalam penanggulangan bencana responsive gender yang dilaksanakan sesuai dengan analisis gender menggunakan data terpilah.

Penelitian relevan yang dilaksanakan oleh peneliti yakni penelitian yang berjudul Peran Perempuan dalam Kegiatan Pariwisata di Kampung Wisata tebing Tinggi Okura Kota Pekanbaru (Faradila Andani, 2017) penelitian ini mendeskripsikan peran perempuan pada kegiatan pariwisata di Pekanbaru. Persamaannya dengan penelitian ini adalah sama-sama membahas peran perempuan. Dan perbedaannya peran perempuan dalam kegiatan pariwisata sedangkan yang akan diteliti oleh penulis adalah peran perempuan dalam pengurangan resiko bencana gempa bumi dan tsunami. Sementara itu penelitian relevan selanjutnya yakni Pemetaan Kerentanaan Politik Korban Benacana Alam Dan Indeks Kerentanan Bencana: Gempa Kota Padang 2009 (Emelia Yustiningrum dkk, 2012)'. Hubungannya adalah sama mendeskripsikan kembali/mengingatkan kembali korban jiwa yang rentan pada gempa 2009 di Kota Padang. Dan perbedaannya lebih meneliti pemetaannya 
sedangkan penelitian yang akan dilakukan oleh penulis peran perempuannya dalam pengurangan resiko bencana.

\section{METODE PENELITIAN}

Pada penelitian yang dilaksanakan menggunakan pendekatan kualitatif dengan cara metode deskriptif. Deskriptif Kualitatif yaitu menggambarkan secara fakta sesuai dengan kenyataan yang ada di lapangan. Lokasi penelitian ditentukan dengan cara menyesuaikan lokasi Kelurahan Air Tawar Barat sebagai lokasi yang sesuai dengan permasalahan yang ada dilapangan. Teknik untuk menentukan seorang informan penelitian yang tepat sasaran dengan cara purposive sampling sehingga dapat mengumpulkan data yang fakta yakni Kasi Pencegahan dan Kesiapsiagaan BPBD Kota Padang, Kepala dan Anggota KSB Kelurahan Air Tawar Barat, LSM, Penanganan Gender, Masyarakat. Teknik pengumpulan data dengan cara obervasi, wawancara, dan dokumentasi. Teknik analisis data yakni dengan reduksi, penyajian data dan penarikan kesimpulan. Teknik keabsahan data peneliti yaitu triangulasi sumber.

\section{HASIL DAN PEMBAHASAN}

Kendala perempuan dalam pengurangan resiko bencana gempa bumi dan tsunami di Kelurahan Air Tawar Barat

Kendala merupakan suatu faktor yang dapat menghambat suatu proses program yang dilaksanakan secara internal maupun eksternal dari organisasi. Berdasarkan hasil penelitian, peneliti menemukan adanya kendala peran perempuan dalam pengurangan resiko bencana gempa bumi dan tsunami di Kelurahan Air Tawar Barat pada pelaksanaanya. Sesuai dengan teori Hansen dan Mowen yakni adanya hambatan yang terjadi berasal dari organisasi atau perusahaan tersebut (Hansen 2007). Dan berdasarkan hasil penelitian, ada beberapa hambatan yaitu secara internal dan eksternal pada kendala peran perempuan dalam pengurangan resiko bencana gempa bumi dan tsunami di Kelurahan Air Tawar Barat.

\section{Kendala Internal}

Anggota Kelompok KSB di Kelurahan Air Tawar Barat yang dibentuk oleh BPBD Kota Padang perempuan hanya dilibatkan sedikit dengan jumlah 23 orang, laki-laki 18 orang dan perempuan hanya 5 orang. Dan pada umumnya laki-laki yang lebih banyak dilibatkan walaupun dibentuk dengan cara sukarela siapa mau dan mampu, akan tetapi peran perempuan juga sangat penting dalam pengurangan resiko bencana gempa bumi dan tsunami di Kelurahan Air Tawar Barat.

Pemahaman para perencana tentang kesetaraan dan keadilan gender dalam pengurangan resiko bencana gempa bumi dan tsunami masih sangat minim. Seperti yang tertuang dalam Badan Nasional Penanggulangan Bencana (BNPB) telah menetapkan sebuah peraturan Kepala BNPB Nomor 13 Tahun 2014 yakni tentang Pengarustamaan Gender pada bidang Penanggulangan Bencana. pada pasal 5 perka ini mengemukakan bahwasannya dalam penyusunan kebijakan, kegiatan dan program dalam penanggulangan bencana responsive gender yang dilaksanakan sesuai analisis gender dengan menggunakan data yang terpilah. BPBD Kota Padang dan KSB Kelurahan Air Tawar Barat Pada umumnya melibatkan kelompok perempuan hanya diperan kan sebagai peran pembantu didapur dan menghilangkan trauma pada anak, mengingat kodrat perempuan adalah lemah dan pada kenyataannya perempuan juga memiliki hak dan kewajiban dalam menyampaikan pendapat dan perempuan juga bisa turun kelapangan untuk kegiatan sosial akan tetapi laki-laki lebih didahulukan. terjadinya Kesejangan gender merupakan suatu kendala yang sangat sulit diatasi.

Peraturan Daerah Kota Padang No 18 Tahun 2018 tentang Rencana Aksi Daerah Pengarustamaan Gender Kota Padang Pada tahun 2018, pada pasal 3, yang berbunyi bahwa dalam memberikan arah da pedoman 
bagi pelaku yang terlibat didalam pembangunan merupakan hal yang diupayakan untuk pengarustamaan gender. Dan kegiatan dalam penguranagn resiko bencana gempa bumi dan tsunami harus dijalankan secara psrtisispatif dan responsive. Jika sosilaisasi yang diadakan tidak merata kepada seluruh warga Kelurahan Air tawar Barat, maka itu dinyatakan tidak partisispatif dan responsif.

Wadah/tempat sosialisasi dan dana desa juga merupakan kendala yang sulit diatasi, yang mana kendala wadah/tempat untuk sosialisasi yang dilaksanakan oleh KSB di Kelurahan Air Tawar Barat tidak ada. KSB melaksanakan sosialisasi bencana gempa bumi dan tsunami dari rumah ke rumah, dan itu sangat tidak efektif. Dan dana desa seharusnya bisa digunakan untuk melakukan sosialisasi dan dapat membeli sarana dan prasarana, akan tetapi KSB sampai saat ini masih sulit mendapatkan dana dari atas untuk melakukan kegiatan kebencanaan gempa bumi dan tsunami, bahkan karena sekarang Negara diancam masalah bahkan sudah sampai ke daerah kita yaitu covid-19, maka dana desa untuk kegiatan bencana dialihkan ke covid-19.

\section{Kendala Eksternal}

Pemahaman dari masyarakat perempuan masih belum maksimal, dikarenakan kurangnya pemahaman dan salah presepsi mengenai sosialisasi pengurangan resiko bencana gempa bumi dan tsunami di anggap hanya untuk menakut-nakuti padahal pemerintah melakukan kegiatan dan program tersebut untuk dapat mengurangi resiko bencana gempa bumi dan tsunami seperti korban jiwa. BPBD Kota Padang sudah membentuk KSB di setiap 104 Kelurahan yang ada di Kota Padang, guna dibentuk KSB yaitu untuk mempermudah masyarakat mendapatkan sosialisasi dan manajemen bencana yang rutin dan merata untuk seluruh masyarakat. Bahkan sempat diwaktu pelaksanaan sosialisasi masyarakat ada juga yang menolak tidak mau ikut serta dalam kegiatan sosialisasi.
Kesadaran, kewaspadaan, dan kepedulian masyarakat terutama perempuan masih sangat minim, Kendala yang sangat sangat sulit yaitu untuk mengubah mindset masyarakat, tergantung dan kembali kepada masyarakatnya sendiri, yang mempunyai prinsip bahwa semua sudah takdir, dan hanya bisa pasrah jika gempa dan tsunami terjadi kalau bisa diushakan lari kenapa tidak, terutama bagi masyarakat yang tinggal ditepi pantai, takut pasti kalau tinggal ditepi pantai, akan tetapi keadaan memaksa karena ekonomi keluarga. Dan jika ada kegiatan sosialisasi dari kelurahan dan simulasi biasanya lakilaki saja yang ikut serta, perempuan jarang sekali hanya sedikit. tanpa adanya usaha yang dilakukan dan sosialisasi yang dilakukan oleh KSB, masyarakat beranggapan hanya untuk menakut-nakuti masyarakat. Perempuan harus tahu akan pentingnya edukasi, pemahaman, kesadaran, kepedulian, kewaspadaan dan manajemen bencana untuk masyarakat terutama perempuan karena perempuan merupakan yang paling rentan jika terjadi bencana gempa bumi dan tsunami. Dan tidak mungkin memaksakan masyarakat yang tidak mau tahu untuk bisa mengikuti kegiatan bencana di Kelurahan Air Tawar Barat. karena KSB dibentuk secara sukarela untuk memberikan edukasi mengenai bencana gempa bumi dan tsunami yang bersumber dari BPBD Kota Padang untuk masyarakat di setiap Kelurahan di Kota Padang.

Ketidaksetaraan gender dirasakan oleh beberapa kelompok perempuan seperti ibuibu PKK dan beberapa masyarakat perempuan lainnya yang ingin dilibatkan dalam kegiatan bencana gempa bumi dan tsunami dalam rangka pengurangan resiko bencana, mengingat gempa bumi Kota Padang 11 tahun yang lalu yang melenyapkan banyak korban jiwa, dan perempuan lah yang lebih banyak menjadi korban jiwa, aka tetapi dari BPBD Kota Padang belum ada kegiatan bencana gempa bumi dan tsunami khusus perempuan di Kota Padang, dan pada umumnya jika ada 
kegiatan kebencanaan lebih dibutuhkan dan dilibatkan adalah kelompok laki-laki. Sering kali perempuan merasa minder jika mereka dilibatkan dalam kegiatan kebencanaan, dan mereka lebih menyerahkan semuanya kepada kelompok laki-laki karena beberapa dari kelompok perempuan sering kali mengap dirinya lemah dan tidak bisa melakukan apa-apa selain menurus rumah tangga, tugas domestik, dan mengurus anak.

\section{PENUTUP}

Berdasakan hasil penelitian sesuai dengan yang diteliti, maka peneliti dapat menyimpulkan bahwasannya: Kendala peran perempuan dalam pengurangan resiko bencana gempa bumi dan tsunami masih sulit diatasi, karena pemahaman, kesadaran, kewasapadaan dan kepedulian masyarakat perempuan masih minim, Kendala internal dan eskternal karna mengingat perempuan merupakan makhluk yang lebih rentan, maka sangat sulit untuk perempuan bisa berperan dalam kegiatan tersebut untuk dilibatkan oleh perencana. Kendala Internal: kurangnya keterlibatan kelompok perempuan dalam kegiatan kebencanaan, kurangnya pemahaman para perencana tentang keadilan dan kesetaraan gender, dan minimnya sarana dan prasarana dan anggaran desa untuk kegiatan kebencanaan. Kendala eksternal: pemahaman, kesadaran, kewasapadaan, kepedulian dan partisipasi masyarakat masih sangat minim dan kesenjangan gender masih dirasakan oleh beberapa kelompok masyarakat di Kelurahan Air Tawar Barat.

\section{DAFTAR KEPUSTAKAAN}

Badan Nasional Penanggulangan Bencana (BNPB) Nomor 13 Tahun 2014 yakni tentang Pengarustamaan Gender pada bidang Penanggulangan Bencana.

Deny Hidayati, dkk. (2006). Kajian Kesiapsiagaan Masyarakat dalam Mengantisipasi Bencana Gempa Bumi dan Tsunami. LIPI-UNESCO. 7 November 2012.

Hadiyati, Siti Nur hafidah.2019. 'Pemberdayaan Perempuan sebagai Bentuk Penguatan Strategi Pengarusutamaan Gender dalam Situasi Bencana di Kabupaten Klaten.'”Jurnal SOLMA. 8(1), 63-72.

Hansen. (2007). Akuntansi Manajemen. Jakarta: Salemba Empat.

Hastuti, 2016, "Peran Perempuan Dalam Menghadapi Bencana Di Indonesia”, dalam Jurnal Geomedia, 14(2), 13-21.

Nurjanah, dkk. 2011. Manajemen Bencana. Bandung: Alfabeta.

Permana, R. 2008. Mengubah Paradigma Penanganan Bencana di Indonesia. http://wjdrsc.files.wordpress.com/2008 /03/paradigmabarupenangananbencana-di-indonesia.pdf. Diakses tanggal 14 Mei 2008.

Permana, .C.E .(2010) .Kearifan Lokal Masyarakat Baduy dalam Mitigasi Bencana Jakarta: Wedatama Widya Sastra.

Puspitawati, Herien. (2013). Konsep, Teori Dan Analisis Gender.

RR. Emelia Y, dkk. (2012). Pemetaan Kerentanan Politik Korban Bencana Alam Dan Indeks Kerentanan Bencana:Gempa Kota Padang 2009. LIPI. 237-252.

Undang-undang Republik Indonseia Nomor 24 Tahun $2007 \quad$ Tentang Penanggulangan Bencana.

Bappenas. (2001). Gender analysis Pathway (GEP). 